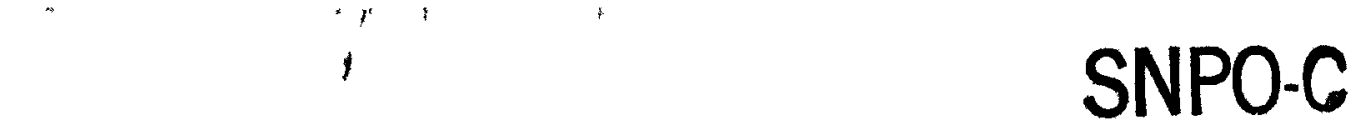

\title{
REACRD COPY
}

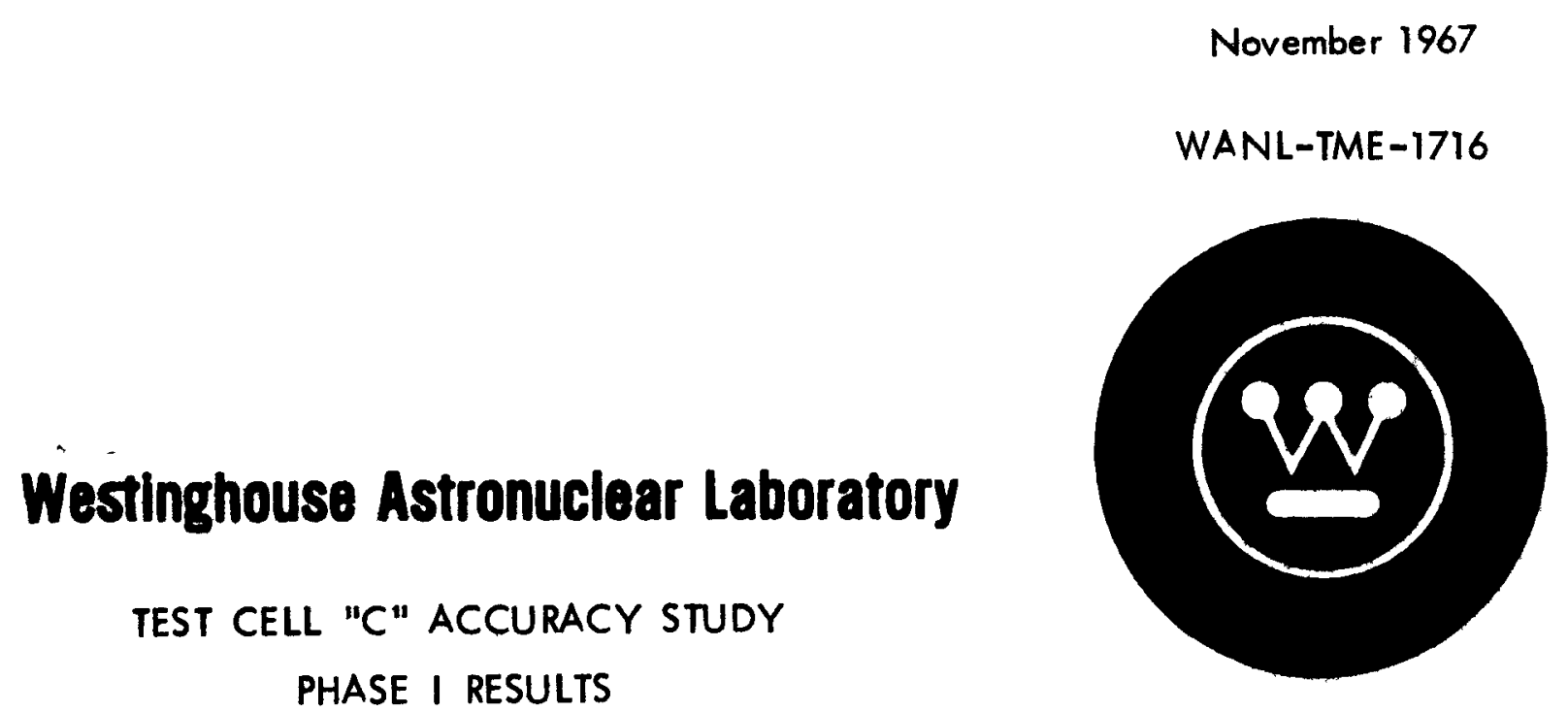




\section{DISCLAIMER}

This report was prepared as an account of work sponsored by an agency of the United States Government. Neither the United States Government nor any agency Thereof, nor any of their employees, makes any warranty, express or implied, or assumes any legal liability or responsibility for the accuracy, completeness, or usefulness of any information, apparatus, product, or process disclosed, or represents that its use would not infringe privately owned rights. Reference herein to any specific commercial product, process, or service by trade name, trademark, manufacturer, or otherwise does not necessarily constitute or imply its endorsement, recommendation, or favoring by the United States Government or any agency thereof. The views and opinions of authors expressed herein do not necessarily state or reflect those of the United States Government or any agency thereof. 


\section{DISCLAIMER}

Portions of this document may be illegible in electronic image products. Images are produced from the best available original document. 
November 1967

\title{
WANL-TME-1716 \\ TEST CELL "C" ACCURACY STUDY \\ PHASE I RESULTS
}

\author{
Submitted by \\ Westinghouse Electric Corporation \\ Astronuclear Laboratory \\ Pittsburgh, Pennsylvania, 15236
}

PREPARED BY:

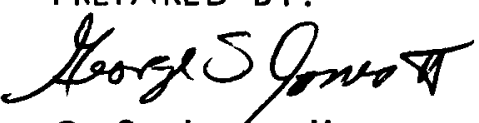

G. S. Jones, II

Systems Development

W. H. Harton

W. H. Horton

Reliability

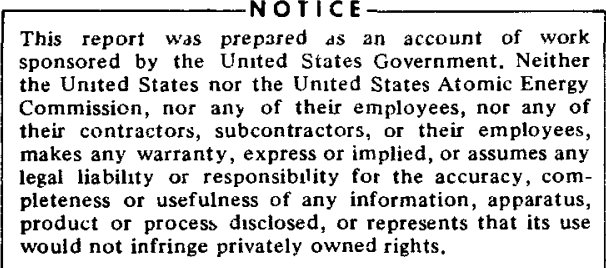

nt. Neither the United States nor the United States Atomic Energy ir employees, makes any warranty, express or implied, or assumes any product or process disclosed, or represents that its use would not infringe privately owned rights.

\section{APPROVED BY:}

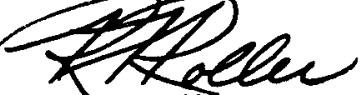

R. F. Roller, Manager

Systems Development

Electronics and Instrumentation
INFORMATION CATEGORY UNCLASSIFIED

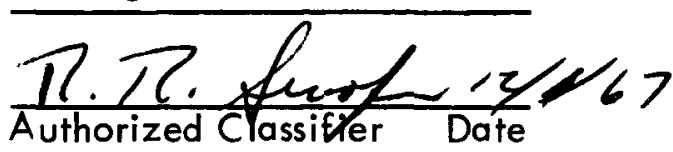

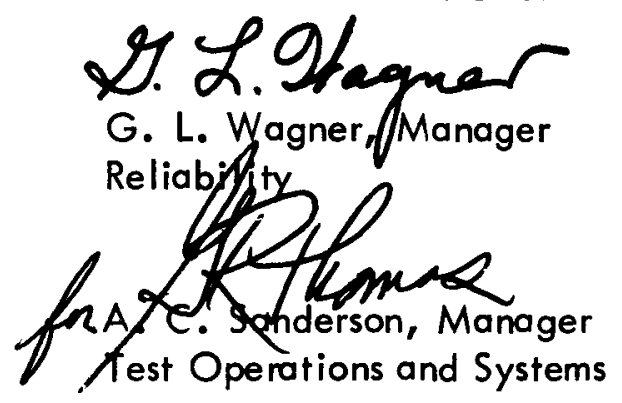

Prepared under Project NE-7730 
TABLE OF CONTENTS

1.0 INTRODUCTION--

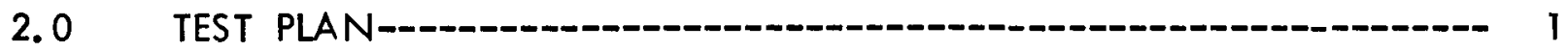

3.0 DATA COLLECTION AND PRELIMINARY DATA REDUCTION--------- 2

4.0 DEFINITION OF ACCURACY COMPONENTS--

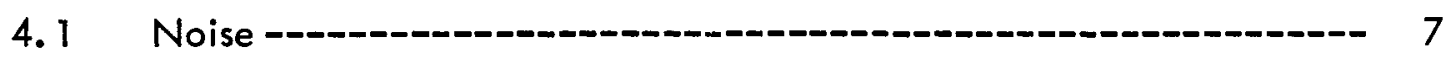

4. 2 Linearity ----- 7

4.3 Drift --_-_- 7

5. 0 DATA ANALYSIS AND RESULTS-- 8

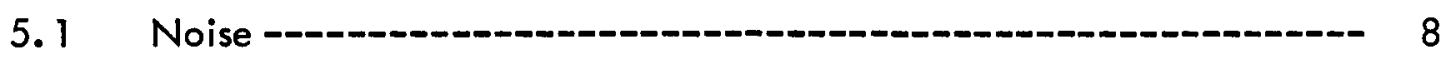

5.2 Linearity and Drift-- 10

6.0 COMPARISON OF TEST CELL "C" AND TEST CELL "A" RESULTS ---- 14

6. 1 Accuracy at Test Cell "C" --- 14 


\section{$1.0 \quad$ INTRODUCTION}

In conjunction with the Phoebus IB-EPIOA test run several data acquisition system calibration runs were made. Prior to this test run discussions among personnel from SNPO, AGC, WANL, NTO, and LASL-NRDS had been held to establish a plan for an accuracy study of the Test Cell "C" narrow-band system, using data from these calibration runs. The Test Cell "C" system is quite similar to that for Test Cell "A" for which an extensive accuracy study was completed in 1965 (for more information, see WANL-TME-1372, dated February 1966). Because of the similarity, all agreed that a complete study for Test Cell " $C$ " would be unwarranted at this time, but that some study was needed to demonstrate the similarity and to ascertain whether or not there are any inconsistencies between the two cells. This report is to present the test plan used to sample the Phoebus IB calibration data, a brief discussion of the sampled data and their analysis, and the results and conclusions derived from the analyses of the data for this study.

\subsection{TEST PLAN}

The Test Cell " $\mathrm{C}$ " narrow band system can be broken down into two categories; the low-level system, containing approximately 850 data channels, and the high-level system, containing approximately 470 data channels (for a complete description, see LASL J-17-547, dated October 7, 1967). Texas Instrument (TI) multiplexers are used in the high-level system as contrasted to the use of both "old" and "new" Systems Engineering Laboratory (SEL) multiplexers in the low-level system. Test Cell "A" accuracy study results had indicated that system accuracy is dependent upon multiplexer type. That study also proved that the data channel configuration (dependent upon the transducer input) affected the system accuracy. To evaluate the applicability of these same effects at Test Cell " $\mathrm{C}$ ", the test plan derived from earlier discussions required data from at least two multiplexers for each multiplexer type and from at least two (if possible) data channels for each channel configuration on each type of multiplexer. The test plan also required data from two runs per day over at least four different days (to evaluate possible "short term" 
(W. Astronuclear

WANL-TME-1716

and "long term" drift). As indicated earlier, data to satisfy these requirements were to be selected from those data obtained during the Phoebus IB calibration runs. Table I gives the data channels (multiplexer-channel configuration combinations) selected for study; the calibration run dates and times for which data were to be sampled are also given. As may be noted from this table, the requirements of the test plan were fulfilled by the selection of 40 channels, covering two multiplexers for each of the three multiplexer types; covering, for the most part, two channels for each multiplexer (overall, five basic channel configurations are represented); and covering data from two runs per day over six different days (actual test period was 18 days). Data for these 40 channels, as taken during the calibration runs (as given in Table 1, data taken at 12 different times) were to be evaluated to estimate the noise, linearity and drift components of the Test Cell "C" Data Acquisition System.

\subsection{DATA COLLECTION AND PRELIMINARY DATA REDUCTION}

Activation of a transducer during a reactor test or stimulation by a power supply during calibration produces an analog signal which is conditioned by the data acquisition channel components. The transformed signal is transmitted over the long lines to the control point where it is recorded in analog format on a tape designated as N1. Over specific time intervals and at specific sampling rates, the analog data are digitized and decommutated by equipment under control of the CDC-160A computer (controlled by input cards and manual switches) to produce a digital tape, designated N2. In converting the analog data to digital data, either of two computer codes, ENIGMA or NDRS may be used. Use of ENIGMA results in data that are termed "normalized" while use of NDRS results in "unnormalized" data. Digital data on these N2 tapes are further processed to yield a tape designed N3, containing data expressed in engineering units. Calibration run data on N2 tapes are processed by a special program to produce a tape for print output containing a normal statistical analysis of the calibration data. Calibration run data for the 40 channels were processed by this special program, consolidated on a single tape, and 


\section{TABLE I}

SELECTED CHANNEL PIN NUMBER VERSUS CHANNEL CONFIGURATION

\section{$\underline{\text { (TRANSDUCER TYPE) }}$}

\begin{tabular}{lccccccc} 
Multiplexer Type & $\begin{array}{c}\text { Strain } \\
\text { Gage }\end{array}$ & $\begin{array}{c}\text { Swept } \\
\text { Pot }\end{array}$ & $\begin{array}{c}\text { Resistance } \\
\text { Thermometer }\end{array}$ & Thermocouple & Bridge \\
\cline { 1 - 1 } HL-11 & Texas Inst. & $03 \& 29$ & $35 \& 36$ & $37 \& 38$ & $11 \& 12$ & $30 \& 31$ \\
HL-18 & Texas Inst. & 42 & $09 \& 21$ & $13 \& 14$ & 19 & $07 \& 08$ \\
LL-13 New SEL & & & $24 \& 25$ & $39 \& 40$ & $27 \& 28$ \\
LL-15 New SEL & & & $04 \& 05$ & $10 \& 11$ & $06 \& 07$ \\
LL-19 Old SEL & & & 21 & $25 \& 26$ & $05 \& 27$ \\
LL-20 Old SEL & & & 37 & $26 \& 27$ & $47 \& 48$
\end{tabular}

PHEOBUS IB CALIBRATION RUN DATES AND TIMES

\begin{tabular}{lccc} 
Date & $\begin{array}{c}\text { Control Room Time } \\
\text { (Seconds from 0700) }\end{array}$ & $\begin{array}{c}\text { Approximate } \\
\text { Time of Day }\end{array}$ \\
\cline { 2 - 4 } $1-30-67$ & 5871 & 6021 & 0830 \\
$1-31-67$ & 4761 & 4901 & 0815 \\
$2-1-67$ & 6451 & 6611 & 0845 \\
$2-2-67$ & 77451 & 77811 & 0430 \\
$2-3-67$ & 77061 & 77241 & 0415 \\
$2-15-67$ & 19401 & 19541 & 1230
\end{tabular}


the tape shipped to WANL for further analysis. In processing the analog data for these channels, both the ENIGMA and NDRS computer codes were used; thus both "normalized" and "unnormalized" data were to be analyzed.

Tables 2 and 3 contain examples of the normal statistical analysis of the calibration data for a particular channel at a particular time. Table 2 contains the analysis of the data from the 11 calibration steps (0\% to $100 \%$ of full scale in $10 \%$ intervals) as resulting from the use of the ENIGMA code (normalized data) while Table 3 contains that resulting from the use of the NDRS code (unnormalized data). For the 12 calibration runs for each of the 40 channels selected for this accuracy study, an analysis like that in either Table 2 or 3 was performed at NRDS, using both the normalized and unnormalized data. This preliminary analysis resulted in 960 sets of data in summarized form. As mentioned earlier, these sets of data were consolidated on a single tape and sent to WANL for further analysis.

Referring to either Table 2 or Table 3, the data of interest in this accuracy study are those data found in the columns headed "average step value E.U." (engineering units as a per cent of full scale) and "standard deviation" (as a per cent of full scale). In the special program used to generate these data (to summarize the calibration run data) the average step value E.U. is an arithmetic average of 18 values sampled from the values obtained at a particular calibration step during a single calibration run. The standard deviation, $s$, is obtained from the expression,

$$
s=\sqrt{\frac{\sum_{i=1}^{18}\left(x_{i}-\bar{x}\right)^{2}}{17}} .
$$

Where: $X_{i}$ is the digital value of the $i$ th data point, $\bar{x}$ is the average of all 18 data points taken on this calibration step. 


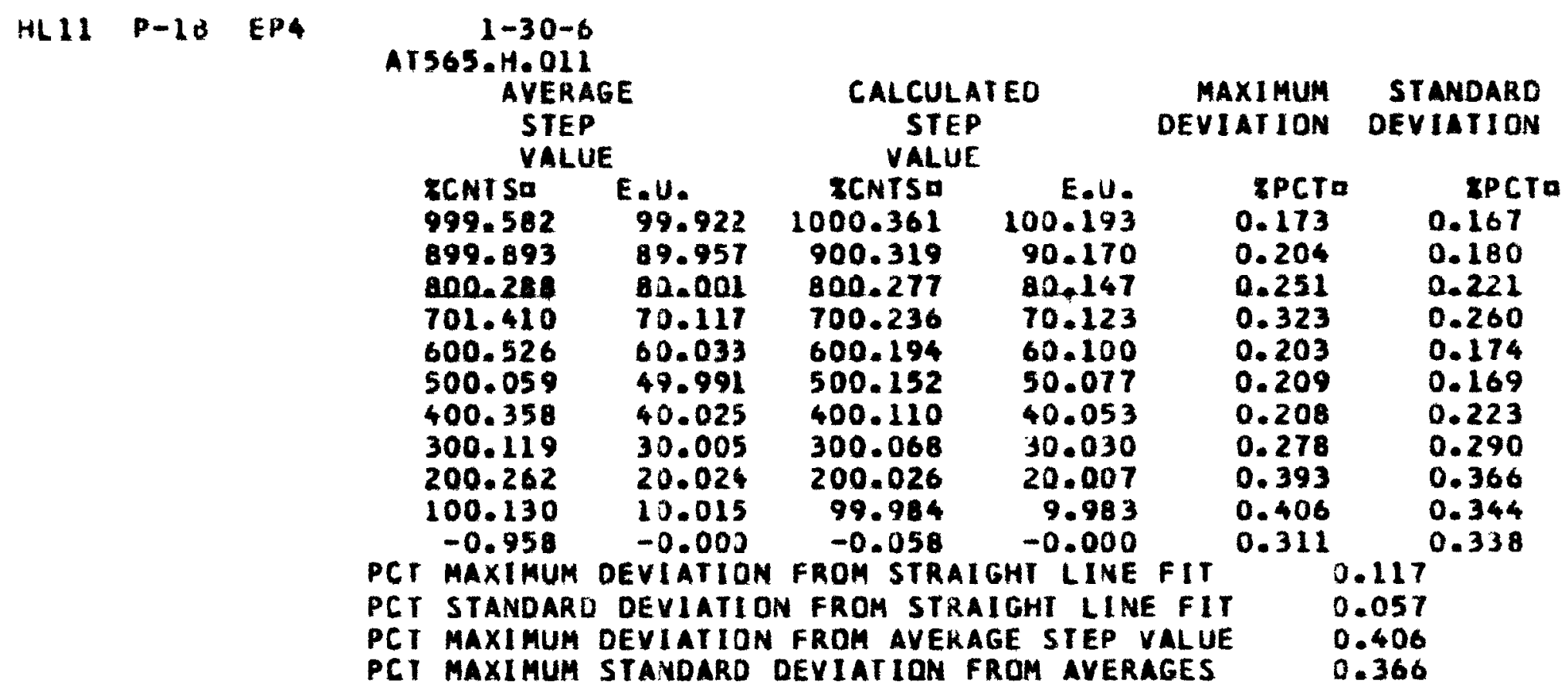

TABLE 2

EXAMPLE OF NORMALIZED DATA 


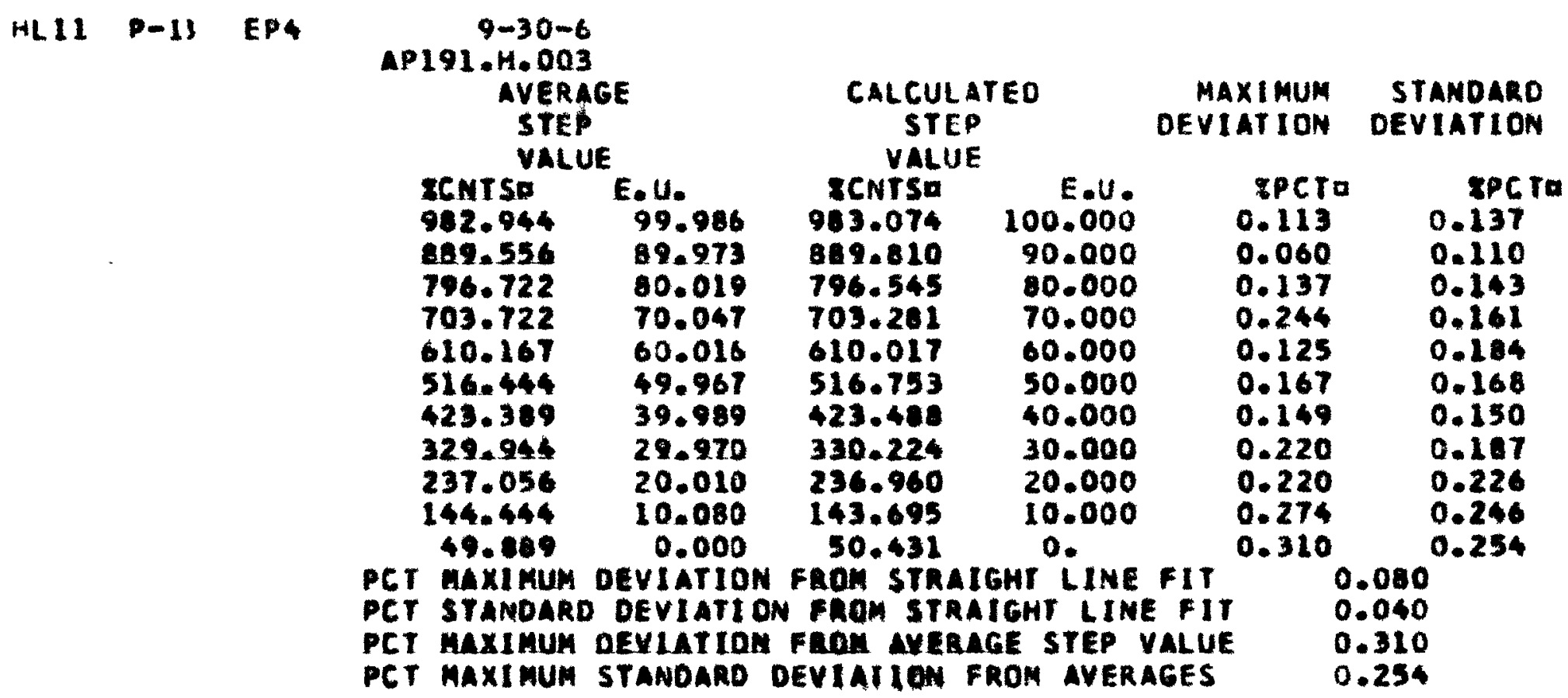

\section{TABLE 3}


(2) Astronuclear

From these summarized data, the average step value E.U. and the standard deviation were extracted to estimate (by additional analysis) the accuracy components of noise, linearity, and drift. With 11 values for each of the 960 sets of data, there then existed 10,560 values from which the accuracy of the Test Cell "C" data system could be estimated.

\section{0 DEFINITION OF ACCURACY COMPONENTS}

4. $1 \quad$ Noise

The data system accuracy component of noise is evaluated by a measurement derived from a comparison of the random fluctuations in signal output to the average of the output under essentially constant input conditions. In this analysis the noise measurement is obtained by the calculation of a standard deviation of the data signals from the average signal value, as discussed earlier. The noise component is thus estimated by this standard deviation.

\section{2 Linearity}

For a constantly-varying signal applied at the data system signal conditioner, a corresponding proportional output should be obtained if the system is linear. In actuality, deviations from a linear relationship may be experienced; such deviations reflect the nonlinearity of the data system.

Non-linearity is determined by taking the average step values, fitting to these data a linear relationship by the method of least squares, and comparing the deviations from the linear relationship to the noise for the same data. Only when the non-linearity deviations are greater than the noise of the system is the linearity component said to exist.

\subsection{Drift}

For a full scale input signal applied at several distinctly separate times, some variation in indicated output may be expected. This variation represents full scale drift (or gain instability) in the channel. In a manner similar to full scale drift, zero offset 
drift is represented by the variations in indicated output for zero input signals applied at several distinctly separate times. For this study, an evaluation of the data system drift component was made by comparing the variations in the average calibration curves taken at several distinctly separate time periods with the variation expected from the system noise. Thus, full scale and zero offset drift were combined into one overall drift value.

\subsection{DATA ANALYSIS AND RESULTS}

From the previous discussion, it is obvious that each calibration run produced estimates of noise for a single channel, these estimates being the standard deviations computed in the special program used by NTO to reduce the data. Standard deviations, s's,

are difficult to analyze per se; however, variances, $s^{2} s$, are readily amenable to analysis if their logarithms are used. The analytical technique used is the analysis of variance as described in many texts on statistical methods and as briefly described in WANL-TME1372 covering the Test Cell "A" accuracy study.

\section{5. $1 \quad$ Noise}

For each channel, the 132 noise variances were analyzed by the analysis of variance technique. The results of the analyses for those channels with in a multiplexer were essentially the same. Average variance estimates for the 40 channels are given in Table 4. Referring to this table, it can be seen that the channels within any multiplexer are not markedly different insofar as their average variance estimates of noise are concerned. (From a single analysis for each multiplexer, channels within any multiplexer were not significantly different statistically.) However, a comparison of the average variance estimates for each multiplexer will indicate that the new SEL multiplexers are nearly alike and much less noisy then either the old SEL or TI multiplexers. In addition, it might be noted that the two TI multiplexers are in turn almost the least noisy and the most noisy, indicating a high variability in noise capability. One additional fact seen in this table is that the normalized data reduction increases the estimates significantly. Apparently, this normalizing data reduction produces an increase in noise. 


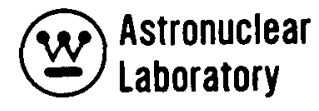

WANL-TME-1716

\section{TABLE 4}

\section{AVERAGE VARIANCE ESTIMATES OF NOISE (PER CENT OF FULL SCALE)}

\begin{tabular}{|c|c|c|c|c|c|c|c|}
\hline Multiplexer & Type & \multirow[t]{2}{*}{$\begin{array}{l}\text { Average } \\
\text { Multiplexer } \\
\text { Variance } \\
\end{array}$} & \multirow{2}{*}{$\begin{array}{l}\text { Resistance } \\
\text { Thermometer } \\
\text { Unnormalized }\end{array}$} & Thermocouple & \multirow[t]{2}{*}{ Bridge } & \multirow[t]{2}{*}{$\begin{array}{l}\text { Swept } \\
\text { Pot } \\
\end{array}$} & \multirow[t]{2}{*}{$\begin{array}{l}\text { Strain } \\
\text { Gage }\end{array}$} \\
\hline & & & & Data & & & \\
\hline Texas Inst. & $\begin{array}{l}\mathrm{HL}-11 \\
\mathrm{HL}-18\end{array}$ & $\begin{array}{l}.03191 \\
.07592\end{array}$ & $\begin{array}{l}.03162 \\
.03089 \\
.07956 \\
.07398\end{array}$ & $\begin{array}{l}.03008 \\
.03239 \\
.07466\end{array}$ & $\begin{array}{l}.03251 \\
.03523 \\
.07501 \\
.07562\end{array}$ & $\begin{array}{l}.03273 \\
.03236 \\
.07589 \\
.07610\end{array}$ & $\begin{array}{l}.03303 \\
.03141 \\
.07668\end{array}$ \\
\hline New SEL & $\begin{array}{l}L L-13 \\
L L-15\end{array}$ & $\begin{array}{r}.02825 \\
.03171\end{array}$ & $\begin{array}{l}.02769 \\
.02743 \\
.03298 \\
.03274\end{array}$ & $\begin{array}{l}.02856 \\
.02870 \\
.02992 \\
.02995\end{array}$ & $\begin{array}{l}.02898 \\
.02815 \\
.03175 \\
.03320\end{array}$ & & \\
\hline Old SEL & $\begin{array}{l}L L-19 \\
L L-20\end{array}$ & $\begin{array}{l}.05756 \\
.04522\end{array}$ & $\begin{array}{r}.06250 \\
.04938\end{array}$ & $\begin{array}{l}.05855 \\
.05418 \\
.04675 \\
.04349\end{array}$ & $\begin{array}{l}.05814 \\
.05482 \\
.04153 \\
.04537\end{array}$ & & \\
\hline
\end{tabular}

Normalized Data

\begin{tabular}{|c|c|c|c|c|c|c|}
\hline Texas Inst. & $\begin{array}{l}H L-11 \\
H L-18\end{array}$ & $\begin{array}{r}.06559 \\
.09505\end{array}$ & $\begin{array}{l}.06634 \\
.06433 \\
.08791 \\
.09129\end{array}$ & $\begin{array}{l}.06022 \\
.06281 \\
.10570\end{array}$ & $\begin{array}{r}.06941 \\
.06869 \\
.07498 \\
.07774\end{array}$ & $\begin{array}{l}.06723 \\
.06728 \\
.07632 \\
.10620\end{array}$ \\
\hline New SEL & $\begin{array}{l}\text { LL-13 } \\
\text { LL-15 }\end{array}$ & $\begin{array}{l}.04835 \\
.03421\end{array}$ & $\begin{array}{l}.04599 \\
.04665 \\
.03296 \\
.03390\end{array}$ & $\begin{array}{l}.05237 \\
.05157 \\
.03537 \\
.03653\end{array}$ & $\begin{array}{r}.04647 \\
.04745 \\
.03197 \\
.03464\end{array}$ & \\
\hline Old SEL & LL-19 & . 09997 & . 10540 & $\begin{array}{l}.10630 \\
.09803 \\
.08505 \\
.07803\end{array}$ & $\begin{array}{r}.09055 \\
.10040 \\
.08076 \\
.08412\end{array}$ & \\
\hline
\end{tabular}


Although the noise estimates for channels within a multiplexer were not significantly different, this is not to say that noise estimates within calibration steps, either within a calibration run or between calibration days (times) were consistent. Table 5 summarizes the results of the analyses for each channel with the significance of the variability in the noise estimates shown. With but one exception (probably a random occurrance), the variability in noise within calibration steps is significant for all channels. The variability within days is not significant with but one exception (again, probably a random occurance) and the variability between days is significant for some multiplexers but not for others. Of those significant variations, the most important (greatest in magnitude) is that seen within calibration steps. In all 40 analyses (80, if the analyses of noise for both normalized and unnormalized data are counted), system noise is fairly consistent for calibration steps from $40 \%$ to $100 \%$ and quite variable and significantly greater from $0 \%$ to $30 \%$. Examples of this can be seen in the standard deviation data of Tables 2 and 3. These variations will be discussed in later paragraphs.

\subsection{Linearity and Drift}

Similar to the analyses of the noise estimates, the analysis of variance technique was used to evaluate the 132 average step values for each channel. The purpose of these analyses was to evaluate the linearity and drift components of accuracy. The results of these analyses are easily summarized. As compared to the average channel noise, no significant drift component was found for any channel.

For the new SEL multiplexers a significant linearity component was noted for all channels. Variance estimates expressing noise plus linearity components are given in Table 6. Comparing these values with those found in Table 4, the linearity effect for the new SEL multiplexers, though significant, is seen to be relatively small. Probably because of the low values for noise on these new SEL units is the linearity effect found significant. In any case, the new SEL multiplexers are still the preferred multiplexers. 
W. Astronuclear

WANL-TME-1716

$\underline{\text { TABLE } 5}$

SUMMARY OF THE EVALUATION OF VARIABILITY IN NOISE ESTIMATES

$\begin{array}{rllllll}\text { Texas Inst. HL-11 -03 } & * & - & - & * & - & - \\ -11 & * & - & * & * & - & * \\ -12 & * & - & - & * & - & * \\ -29 & * & - & - & * & - & - \\ -30 & * & - & - & * & - & - \\ -31 & * & - & - & * & - & - \\ -35 & * & - & - & * & - & - \\ -36 & * & - & - & * & - & - \\ -37 & * & - & - & * & - & * \\ -38 & * & - & - & * & - & - \\ \text { HL-18 }-07 & * & - & * & * & - & - \\ -08 & * & - & * & * & - & - \\ -09 & * & - & * & * & - & - \\ -13 & * & - & * & * & - & - \\ -14 & * & - & * & * & - & - \\ -19 & - & - & * & * & - & * \\ -21 & * & - & * & * & - & * \\ -42 & * & - & * & * & - & *\end{array}$




\section{(w) Astronuclear \\ WANL-TME-1716}

TABLE 5 (Cont' d)

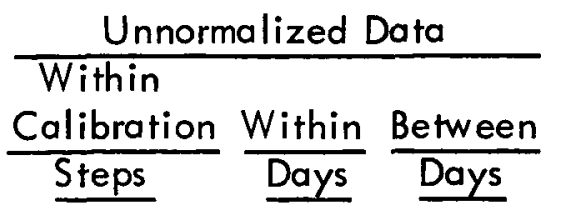

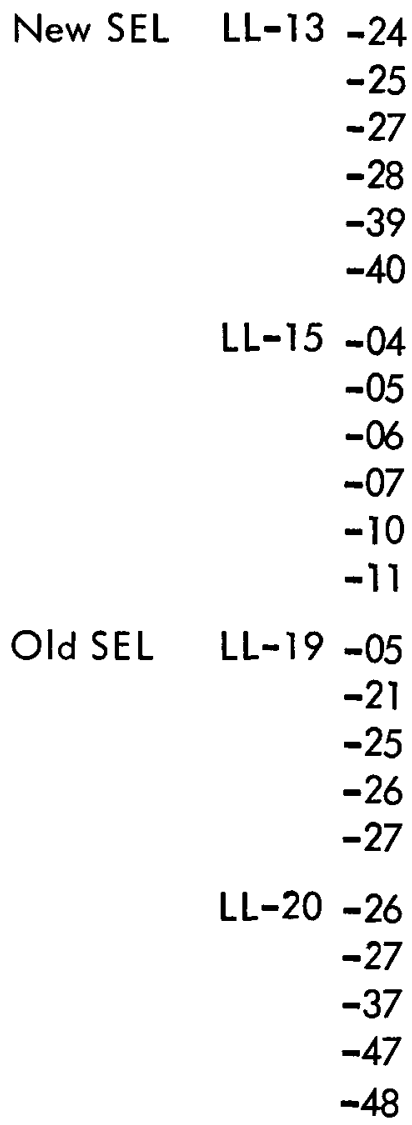

*Variability Significant

-Variability not Significant

$\frac{\text { Normalized Data }}{\text { Within }}$
$\frac{\text { Calibration Within }}{\text { Steps }} \frac{\text { Between }}{\text { Days }} \frac{\text { Days }}{}$

$\begin{array}{ll}- & - \\ - & - \\ - & - \\ - & \text { * } \\ - & - \\ - & \text { * } \\ - & \text { * } \\ - & \text { * } \\ - & \text { * }\end{array}$

$\begin{array}{ll}- & - \\ - & - \\ - & \\ - & \\ - & \\ - & * \\ - & * \\ - & *\end{array}$


Wstronuclear
Laboratory
WANL-TME-1716

TABLE 6

VARIANCE ESTIMATES FOR NOISE PLUS LINEARITY (PER CENT OF FULL SCALE)

\begin{tabular}{|c|c|c|c|c|c|c|}
\hline Multiplexer Type & $\begin{array}{l}\text { Average } \\
\text { Multiplexer } \\
\text { Variance }\end{array}$ & $\begin{array}{l}\text { Resistance } \\
\text { Thermometer }\end{array}$ & Thermocouple & Bridge & $\begin{array}{l}\text { Swept } \\
\text { Pot }\end{array}$ & $\begin{array}{l}\text { Strain } \\
\text { Gage }\end{array}$ \\
\hline & & $\overline{\text { Unnormalized }}$ & & & & \\
\hline
\end{tabular}

Texas Inst. HL-II

$H L-18$

No Linearity Effect - See Noise

$\begin{array}{llllll}\text { New SEL LL-13 } & .03220 & .03170 & .03252 & .03340 \\ & & & .03115 & .03295 & .03147 \\ & & & & & \\ & \text { LL-15 } & .04047 & .04278 & .03736 & .04090 \\ & & .04196 & .03893 & .04115\end{array}$

Old SEL LL-19

$$
\text { LL-20 }
$$

No Linearity Effect - See Noise

$$
\text { Normalized Data }
$$

Texas Inst. HL-11

$$
\mathrm{HL}-18
$$

No Linearity Effect - See Noise

$\begin{array}{llllll}\text { New SEL LL-13 } & .05233 & .04998 & .05637 & .05105 \\ & & & .05032 & .05590 & .05077 \\ & & & & & \\ & \text { LL-15 } & .04492 & .04479 & .04468 & .04310 \\ & & .04506 & .04752 & .04450\end{array}$

Old WEL LL-19

$\mathrm{LL}-20$

No Linearity Effect - See Noise 
The previous statement is verified in Table 7. Table 7 gives three accuracy values for each multiplexer. These values are an average, maximum and minimum. The average values are computed by taking the square roots of the average variances of Table 4 and multiplying these square roots by 2.6 to give $\pm 99 \%$ confidence limits. The maximum and minimum values were obtained in a similar manner after first considering the variability in noise as summarized in Table 5. To be assured of a proper value, the maximum values should be used; however, the average values would be realistic for signal outputs in the upper half of the full scale range. Minimum values are included primarily to indicate how good the system accuracy could be in isolated, though not predictable, cases.

\subsection{COMPARISON OF TEST CELL "C" AND TEST CELL "A" RESULTS}

As stated earlier, one of the purposes of this study was to make a comparison of the accuracy values from the Test Cell "A" study with those from this study of Test Cell "C". Table 8 contains accuracy values which might be compared. The values for Test Cell "A" were taken from Table XIII of WANL-TME-1372 while those for Test Cell " $C$ " are those maximum values of Table 7 adjusted for the inconsequential differences between channels as shown in Table 4. As may be seen from the data of Table 8, a direct comparison of the accuracy values from these two studies cannot be reasonably made because of the differences in multiplexer types between the two systems. However, in the Test Cell "A" study there were three old SEL multiplexers which compare with the two selected for the Test Cell "C" study. This limited area of comparability is insufficient to provide a comprehensive application of Test Cell "A" results to Test Cell "C". On the basis of this study, Test Cell "A" results cannot be considered to apply at Test Cell "C".

\subsection{Accuracy at Test Cell "C"}

Even though a comparison with Test Cell "A " cannot be drawn, sufficient data are available to predict channel accuracy at Test Cell " $\mathrm{C}$ " from the signal conditioner through the data reduction system. These data are sufficient in all respects but one, 


\section{(w) Astronuclear

\section{TABLE 7 \\ ACCURACY VALUES $( \pm 99 \%$ CONFIDENCE LIMITS) FOR \\ PHOEBUS IB-EPIOA CALIBRATION RUNS \\ (PER CENT OF FULL SCALE)}

\begin{tabular}{|c|c|c|c|c|c|c|c|}
\hline & \multicolumn{3}{|c|}{ Unnormalized Data } & \multicolumn{3}{|c|}{ Normalized Data } \\
\hline & & Average & Maximum & Minimum & Average & Maximum & Minimum \\
\hline \multirow[t]{2}{*}{ Texas Inst. } & $\mathrm{HL}-11$ & 0.46 & 0.94 & 0.23 & 0.67 & 1.30 & 0.34 \\
\hline & HL-18 & 0.72 & 1.59 & 0.34 & 0.80 & 1.60 & 0.40 \\
\hline \multirow[t]{2}{*}{ New SEL } & LL-13 & 0.44 & 0.90 & 0.21 & 0.57 & 1.10 & 0.30 \\
\hline & LL-15 & 0.46 & 0.97 & 0.22 & 0.48 & 0.99 & 0.23 \\
\hline \multirow[t]{2}{*}{ Old SEL } & $L L-19$ & 0.62 & 1.30 & 0.30 & 0.82 & 1.60 & 0.41 \\
\hline & LL-20 & 0.55 & 1.10 & 0.27 & 0.75 & 1.50 & 0.38 \\
\hline
\end{tabular}


(2) Astronuclear

WANL-TME-1716

\section{TABLE 8}

COMPARISON OF ACCURACY VALUES ( $\pm 99 \%$ CONFIDENCE LIMITS) FOR CALIBRATION RUNS OF PHOEBUS IB-EPIOA AND

TEST CELL "A" ACCURACY STUDY

\begin{tabular}{|c|c|c|c|c|c|c|c|}
\hline Test & $\begin{array}{c}\text { Multiplexer } \\
\text { Type } \\
\end{array}$ & Multiplexer & $\begin{array}{l}\text { Resistance } \\
\text { Thermometer }\end{array}$ & Thermocouple & Bridge & $\begin{array}{l}\text { Swept } \\
\text { Pot }\end{array}$ & $\begin{array}{l}\text { Strain } \\
\text { Gage } \\
\end{array}$ \\
\hline \multirow[t]{2}{*}{ Phoebus IB } & $\mathrm{TI}$ & $H L-11$ & 0.93 & 0.94 & 0.96 & 0.94 & 0.94 \\
\hline & & $H L-18$ & 1.49 & 1.50 & 1.49 & 1.49 & 1.50 \\
\hline \multirow[t]{4}{*}{ TCA } & $E G \& G$ & $\mathrm{HL}-04$ & & & & 1.14 & \\
\hline & & $\mathrm{HL}-05$ & & & & 1.08 & \\
\hline & & $H L-01$ & & 0.48 & & & 0.42 \\
\hline & & $H L-02$ & & 1.27 & & & 0.68 \\
\hline \multirow[t]{4}{*}{ Phoebus IB } & New SEL & $L L-13$ & 0.89 & 0.90 & 0.89 & & \\
\hline & & LL-15 & 0.98 & 0.96 & 0.97 & & \\
\hline & Old SEL & LL-19 & 1.33 & 1.30 & 1.30 & & \\
\hline & & $L L-20$ & 1.12 & 1.10 & 1.10 & & \\
\hline \multirow[t]{5}{*}{ TCA } & Bendix & LL-05 & 1.14 & & & & 1.21 \\
\hline & & $L L-06$ & 1.28 & & & & 1.25 \\
\hline & Old SEL & LL-09 & 0.60 & 0.60 & & & \\
\hline & & LL-10 & & 1.34 & & & 1.30 \\
\hline & & LL-02 & 1.76 & & & & 1.66 \\
\hline
\end{tabular}


crosstalk. This effect was not significant using the old and new SEL multiplexers at Test Cell "A", and probably would exhibit a similar character if tests had been performed at Test Cell "C".

Data system accuracy is again multiplexer dependent, but independent of the type of channel, transducer, and signal conditioner. Accuracy values, to $99 \%$ confidence are:

$\begin{array}{ll}\text { Texas Instrument Nultiplexer Channels } & 1.6 \% \\ \text { Old Style SEL Multiplexer Channels } & 1.6 \% \\ \text { New Style SEL Multiplexer Channels } & 1.1 \%\end{array}$

It is felt that these figures are valid, and will serve adequately until better information is obtained with future testing.

Cable effects existing between the test car and the signal conditioner, thermocouple referencing effects, crosstalk and frequency response have not been evaluated in this study. 